\title{
Food preservatives - An overview on applications and side effects
}

\author{
Maria Manuela Silva ${ }^{1 *}$, Fernando Cebola Lidon ${ }^{2}$ \\ ${ }^{1}$ ESE Almeida Garrett, Grupo Universidade Lusófona, COFAC, Rua de São Paulo, Lisboa, Portugal, ${ }^{2}$ GeoBioTec, Departamento de Ciências \\ da Terra, Faculdade de Ciências e Tecnologia, Universidade Nova de Lisboa, Caparica, Portugal
}

\section{A B S TR A C T}

\begin{abstract}
Food additives are natural or synthetic substances that can be added to foodstuff in small amounts to perform technological functions, namely colour, sweetness or to extend shelf life. In the European Union an E number identifies all food additives. According to the technological functions twenty-five categories of food additives have been defined. Preservatives, also known as antimicrobial agents, are food additives used to extend the shelf life of food by shielding them against deterioration caused by microorganisms. There are forty five substances used as preservatives, being their applications and purity regulated in the European Union. Although some of these substances are harmless when used in small quantities (e.g., the authorized amounts), the use of others are not without risks to human health. Among large amounts of side effects, skin rashes and itching, breathing difficulty, sneezing or gastrointestinal upsets can be found. This work is a synoptical review of food additives used as preservatives (antimicrobial agents) authorized in the European Union, considering its characteristics, uses and side effects.
\end{abstract}

Keywords: Antimicrobial agents; Applications of preservatives; Food additives; Food preservatives; Side effects of preservatives

\section{INTRODUCTION}

Food additives are substances added intentionally to foodstuff, to increase the durability of the product and enhance or modify its properties, including its appearance, flavor or structure, provided it does not detract from its nutritional value. Substances can be of natural or synthetic origin, usually without appreciable nutritional value, that are added to food in small amounts during the manufacture (industrial change or during packaging).

The use of food additives is regulated by specific laws (namely in the European Union - EU), considering the food where it can be applied, maximum usable quantities, chemical characterization and purity (Directives 95/2/ EC - 1995, 95/31/CE - 1995, 95/45/CE - 1995, 96/83/ CE - 1995, 96/77/CE - 1996, 96/83/CE - 1996, 96/85/ CE - 1996, 98/66/CE - 1998, 98/72/CE - 1998, 99/41/ CE - 1999, 99/75/CE - 1999, 2000/63/CE - 2000, 2001/30/CE - 2001, 2002/46/CE - 2002, 2003/115/ CE - 2003). Besides, in EU every food additive has a code that includes the letter E (for Europe) followed by three or four digits. The numbering scheme follows that of the International Numbering System (INS) as determined by the Codex Alimentarius Committee.

According to the technological function, twenty five categories of food additives have been defined (Lidon and Silvestre, 2007): Preservatives, also known as antimicrobial agents, used to extend the shelf-life of foods by protecting them against deterioration caused by microorganisms; Antioxidants, which extend the shelf-life of foods by protecting them against oxidation; Carriers, used to disperse, dilute, dissolve or otherwise physically modify a food additive, without altering its technological function and without the very substances exerting any technological effect, in order to facilitate its handling, application or use; Acidifying substances, used to increase the acidity of a foodstuff or confer them a sour taste and is widely used in beverages to give them an acid or sour taste similar to the taste of the fruit; Acidity regulators, which alter or control the $\mathrm{pH}$ of foodstuffs; Anti-caking agents, used to reduce the tendency of particles of food to agglomerate; Antifoaming agents, used to prevent or reduce the formation 
of foams; Sparkling, substances that enable homogenous dispersion of a gaseous phase in food, liquids or solids; Emulsifiers, that allow the formation or maintenance of homogeneous mixtures of two or more immiscible phases (like oil and water) in food products; Thickeners, used for increasing the viscosity of foodstuffs, (e.g. they condense and thicken); Stabilizers, which maintain the physicochemical state of food and include substances that allow a homogenous dispersion of two or more immiscible substances (additionally, also might have the ability to retain or enhance the natural color of food - color stabilizers); Emulsifying salts, which disperse proteins (namely these contained in cheese), allowing a homogenous distribution of fat and other components; Gelling agents, used to impart texture to food products with the formation of a gel; Bulking agents, which contribute to the volume of food products; Firming agents, which make foodstuff (namely vegetables and fruits) crispy or interact with gelling agents to produce or strengthen a gel; Glazing agents, that applied to the external surface of the food products gives them a shiny appearance or a protective coating; Flavor enhancers, used to enhance the taste or smell of the food (have a broad spectrum of uses and are especially used in pre-cooked meals); Humectants, which prevent foods from drying (widely used in candy with fillings, chocolates and biscuits); Modified starches, substances obtained after one or more chemical treatments of edible starches, but may also have undergone physical, or enzymatic treatments; Packaging gases, gases introduced into the packaging container before, during or after placing the food products (yet, the air is not considered a packaging gas); Propellant gases, which expel foodstuff from containers (air is not a propellant gas); Raising agents, isolated substances or mixtures, which increase the gas release volume, namely from pasta flour or purées; Sequestrants, which form chemical complexes with metallic ions and thus sequester metal ions, thus preventing them to catalyze decomposition reactions; Colorants, which add or enhance the natural color of food products (can be natural colorants extracted from fruit, vegetable or minerals, or of synthetic origin); Sweeteners, sweet-tasting substances that replace sugar (commonly used in the production of energy-reduced food, therefore light products, foodstuff that do not cause tooth decay and food without added sugars, as well as in the production of dietetic foods).

It is often necessary to use various additives simultaneously, due to the characteristics of the food product, or because the additives themselves can be degraded and need to stabilize by other. Also various additives can be used simultaneously to enhance a particular function (synergistic effect). Some food additives can have various technological functions. In this context, whereas the growth of fungi and bacteria can affect the quality of food, together with other techniques, such as hermetically sealed packaging and cooling, various chemicals are used as anti-microbial agents (Lidon and Silvestre, 2008). These substances are classified (as to its technological function) as preservatives, and its use is EU regulated. Accordingly, this work is a synoptical review of food additives used as preservatives (antimicrobial agents) authorized in the EU, considering its characteristics, uses and side effects.

\section{USES, CHARACTERISTICS AND SIDE EFFECTS OF FOOD PRESERVATIVES}

Following the EU regulation, preservatives are food additives that protect against the action of microorganisms (fungi and/or bacteria) and thereby extend the shelf life of foodstuff. Among the currently used preservatives, sodium chloride (known as salt) is probably the oldest preservative. Organic acids, such as acetic acid (E260), benzoic acid (E210), propanoic acid (E280) and sorbic acid (E200), are also preservatives extensively used in low $\mathrm{pH}$ foods. Nitrates and nitrites are commonly applied to inhibit Clostridium botulinum in foods containing raw meat, such as sausage, ham, bacon and salamis. Sulphur dioxide (E220) and sulphites (E221 - E226 and 224 - 228) are extensively added to control the growth of microorganisms in dry fruits, juices and wines. Nisin (E234) and natamycin (E235) are antibiotics used to growth inhibit growth of bacteria and fungi in various foods.

Various preservatives may also be used isolated or simultaneously. For example, Citrol (R) is an antimicrobial preservative integrating the synergistic action of two components, to inhibit the development of mold. It is an alcoholic solution of citric acid (E330) and sorbic acid (E200). Citrol is a preservative that can be used in bakery products (breads form, soft buns for "hot dog" or hamburger), pizzas and other dough for biscuits.

\section{Sorbic acid and sorbates}

The fungicidal action of the linear chain acids has been known for some time. Among them, the unsaturated acids are those with better recognized effects. Sorbic acid (2,4-hexadienoic acid) (Fig. 1) is an unsaturated carboxylic acid $\mathrm{pK}=4.76$, often used as a food preservative (E 200), which has the advantage of having no odor or flavor when used at the appropriate concentration $(0.3 \%)$.

Sorbic acid can be obtained from rowan berries (Sorbus aucuparia) or may be chemically synthesized. This additive may be present in the form of colorless needles or white powders having a slight characteristic odor (FAO, 2006). The antimicrobial activity of sorbic acid is effective against yeasts, fungi and bacteria weaker. This additive 
Table 1: Sorbic acid and sorbates used as preservatives

\begin{tabular}{lll}
\hline Additive code & Designation & Chemical formula \\
\hline E200 & Sorbic Acid & $\mathrm{CH}_{3} \mathrm{CH}=\mathrm{CHCH}=\mathrm{CHCOOH}$ \\
E201 & Sodium sorbate & $\mathrm{CH}_{3} \mathrm{CH}=\mathrm{CHCH}=\mathrm{CHCOONa}$ \\
E202 & Potassium sorbate & $\mathrm{CH}_{3} \mathrm{CH}=\mathrm{CHCH}=\mathrm{CHCOOK}$ \\
E203 & Calcium sorbate & $\left(\mathrm{CH}_{3} \mathrm{CH}=\mathrm{CHCH}=\mathrm{CHCOO}\right)_{2} \mathrm{Ca}$ \\
\hline
\end{tabular}

Table 2: Benzoic acid, benzoates and p-hydroxybenzoates used as preservatives

\begin{tabular}{|c|c|c|}
\hline $\begin{array}{l}\text { Additive } \\
\text { code }\end{array}$ & Designation & Chemical formula \\
\hline E210 & Benzoic acid & $\mathrm{C}_{6} \mathrm{H}_{5} \mathrm{COOH}$ \\
\hline E211 & Sodium benzoate & $\mathrm{C}_{6} \mathrm{H}_{5} \mathrm{COONa}$ \\
\hline E212 & Potassium benzoate & $\mathrm{C}_{6} \mathrm{H}_{5} \mathrm{COOK}$ \\
\hline E213 & Calcium benzoate & $\left(\mathrm{C}_{6} \mathrm{H}_{5} \mathrm{COO}\right)_{2} \mathrm{Ca}$ \\
\hline E214 & Ethyl p-hydroxybenzoate & $\mathrm{HOC}_{6} \mathrm{H}_{4} \mathrm{COOCH}_{2} \mathrm{CH}_{3}$ \\
\hline E215 & $\begin{array}{l}\text { Sodium salt of ethyl } \\
\text { p-hydroxybenzoate }\end{array}$ & $\mathrm{NaOC}_{6} \mathrm{H}_{4} \mathrm{COOCH}_{2} \mathrm{CH}_{3}$ \\
\hline E216 & Propyl p-hydroxybenzoate & $\mathrm{HOC}_{6} \mathrm{H}_{4} \mathrm{COOCH}_{2} \mathrm{CH}_{2} \mathrm{CH}_{3}$ \\
\hline E217 & $\begin{array}{l}\text { Sodium salt of } \\
\text { p-hydroxybenzoate }\end{array}$ & $\mathrm{NaOC}_{6} \mathrm{H}_{4} \mathrm{COOCH}_{2} \mathrm{CH}_{2} \mathrm{CH}_{3}$ \\
\hline E218 & Methyl p-hydroxybenzoate & $\mathrm{HOC}_{6} \mathrm{H}_{4} \mathrm{COOCH}_{3}$ \\
\hline E219 & $\begin{array}{l}\text { Sodium salt of methyl } \\
\text { p-hydroxybenzoate }\end{array}$ & $\mathrm{NaOC}_{6} \mathrm{H}_{4} \mathrm{COOCH}_{3}$ \\
\hline
\end{tabular}

can be used in many food products, namely in beverages (fruit juices, wine and cider), pastries and partially cooked bakery, cheeses, fruits and vegetables pickled or candied, olives, jams and jellies, nuts, margarine, meat products, sauces, products based on fish and eggs, cooked shrimp, chewing gum, flavoured dairy products, prepared salads, sweets and syrups. In addition to the sorbic acid, sodium, potassium and calcium sorbic acid salts (E201, E202 and E203, respectively) can also be used (Table 1). The salts have a large implementation, due to similar anti-microbial effects, being more soluble in water.

Considering the quantities that are used in the food industry, sorbic acid and sorbates, do not appear to have relevant side effects. However were described possible allergies, usually visible in the form of urticarial (Voss, 2002; Abdulmumeen et al., 2012). Nevertheless, as sorbic acid is metabolized, as some fatty acids, reduces the probability of having other detrimental effects. The use of sorbates, derivatives of boric acid, does not have more side effects that the use of sorbic acid and can be used in similar dosages.

\section{Benzoic acid, benzoates and p-hydroxybenzoates}

In the agro food industry benzoic acid (Fig. 2) has been used as a preservative (E210) and as an antioxidant.

The activity of the benzoic acid is exerted on the cell membranes, and also inhibits enzymes of the citric acid cycle and of the oxidative phosphorylation. Alkali metal salts of benzoic acid (Table 2), in particular sodium benzoate (E211), potassium benzoate (E212) and calcium

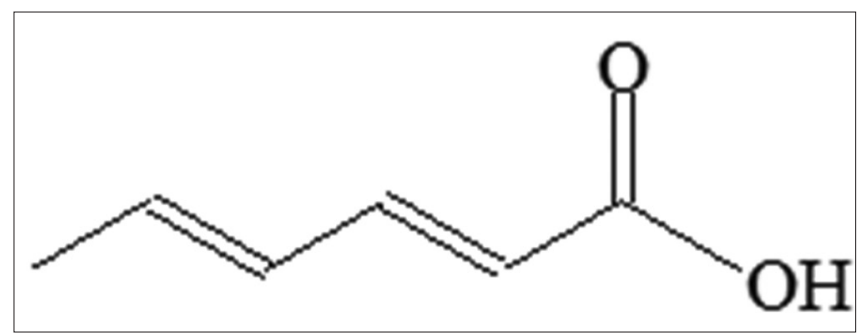

Fig 1. Sorbic acid (E200) structure.

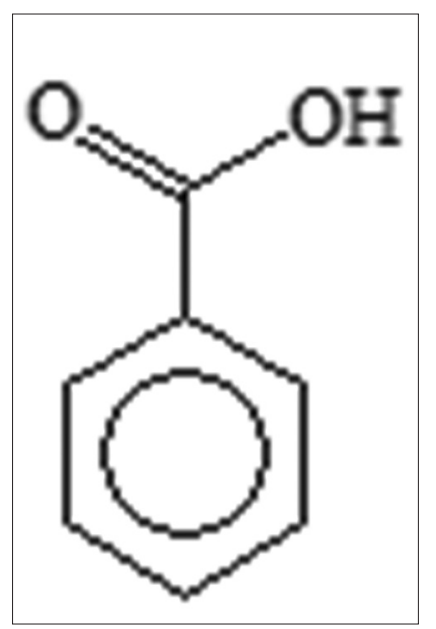

Fig 2. Benzoic acid (E210) structure.

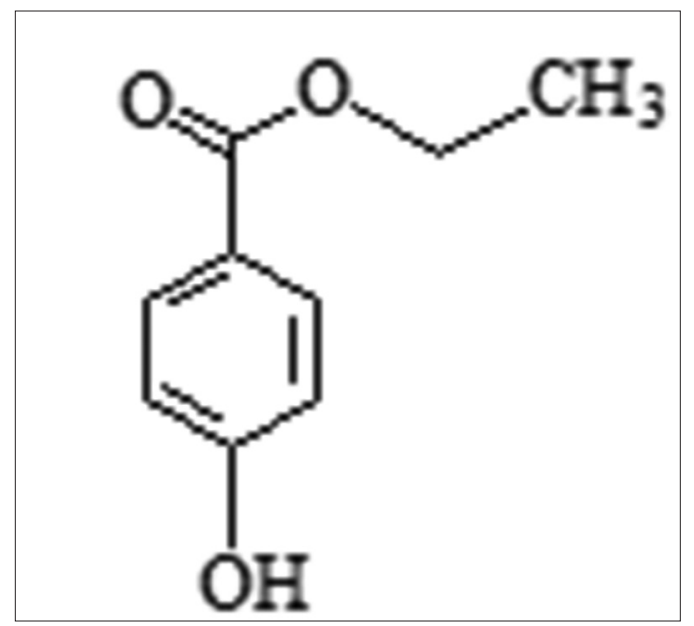

Fig 3. Ethyl p-hydroxybenzoate (E214) structure.

benzoate (E213), are usually applied as preservatives for fruit juice and soft drinks, since benzoic acid is poorly soluble in water. Various p-hydroxybenzoates (E214 to E219) are also used (Table 2; Fig. 3).

The benzoic acid is found in nature, as glucoside, in some fruits (like blueberries and plums) and spices (such as cinnamon and cloves of cloves). However, it is mainly produced synthetically. The antimicrobial action prevails on yeast and fungi and, to a lesser extent, on bacteria. The benzoates and p-hydroxybenzoates are synthesized from 
benzoic acid. Benzoates E211 - E215 and E217 have antimicrobial action against fungi and bacteria. E216 and E218 have antibacterial action. E219 acts better against fungi.

Benzoic acid is used often in combination with other preservatives, especially in acidic foods $(\mathrm{pH} 4-4,5)$ due to its strong dependence of pH. E210 (benzoic acid) and E211, E212 and E213 (benzoates) are used in flavored soft drinks (soft drinks or syrups), non-alcoholic beer, fruit and vegetables pickled or candied, marmalade, jams and jellies (with low sugar or no added sugar), confectionery, products based on fish and eggs, cooked shrimp, sauces, prepared salads, condiments and spices, and cooked beets. The additives E214 to E219 are used gelatinous coatings on meat products, pates, surface treatment of dried meat products, snacks, cereal or potato, nuts and coated confectionery products.

Some studies (Voss, 2002) show that a daily dose of less than $0.5 \mathrm{~g}$ sodium benzoate (E211) is harmless for man, but a lesser dose than $0.4 \mathrm{~g}$ day $^{-1}$ has no risk of accumulation. This additive is renal eliminated as hippuric acid $\left(\mathrm{C}_{6} \mathrm{H}_{5} \mathrm{CONHCH}_{2} \mathrm{COOH}\right)$ and (in case high doses) as glucuronic acid derivatives $\left(\mathrm{C}_{6} \mathrm{H}_{10} \mathrm{O}_{7}\right)$. However, many side effects have been reported. For preservatives ranging between E210 and E213, synthesis of suspected compounds with other substances in the foodstuff have been pointed, which seems to display allergic reactions (Tuormaa, 1994; Abdulmumeen et al., 2012; Inetianbor et al., 2015) (especially in people suffering from intolerance to acetylsalicylic acid, individuals taking antiinflammatory drugs or suffering from asthma or urticarial). Besides, the occurrence of waste neurotoxic organochlorine substances and the promotion of hyperkinesia and gastric irritation was pointed (Voss, 2002). E215 and E219 also seems to include side effects such, as allergic reactions (paresthesia oral level) and, in animal experiments, numbing effects, vasodilatation, cramps and eventually (although still not definitively proven) teratogenicity. Furthermore, E211 seems to aggravate asthma and is suspected to be neurotoxin and carcinogen, and may cause fetal abnormalities and hyperactivity (Inetianbor et al., 2015). The additives E214, E215, E217 and E219 were banned in Australia (Voss, 2002).

\section{Sulphur dioxide and sulphites}

Sulfur dioxide $\left(\mathrm{SO}_{2}\right)$ (E220) and sodium, potassium and calcium sulfites (E221 to E224 and E226 to E228) (Table 3) are used as food preservatives that inhibit the development of yeasts, fungi and bacteria. Their action increases with decreasing $\mathrm{pH}$, mainly due to the action of sulfurous acid $\left(\mathrm{H}_{2} \mathrm{SO}_{3}\right)$ undissociated that predominates at $\mathrm{pH}<3$. Besides, the preservative function, these additives can also
Table 3: Sulphur dioxide and sulfites used as preservatives

\begin{tabular}{lll}
\hline $\begin{array}{l}\text { Additive } \\
\text { code }\end{array}$ & Designation & \multicolumn{1}{c}{$\begin{array}{l}\text { Chemical } \\
\text { formula }\end{array}$} \\
\hline E220 & Sulphur dioxide & $\mathrm{SO}_{2}$ \\
E221 & Sodium sulfite & $\mathrm{Na}_{2} \mathrm{SO}_{3}$ \\
E222 & Sodium hydrogen sulphites, sodium bisulphite $\mathrm{NaHSO}_{3}$ \\
E223 & Sodium metabisulphite & $\mathrm{Na}_{2} \mathrm{~S}_{2} \mathrm{O}_{5}$ \\
E224 & Potassium metabisulphite & $\mathrm{K}_{2} \mathrm{~S}_{2} \mathrm{O}_{5}$ \\
E226 & Calcium sulphite & $\mathrm{CaSO}_{3}$ \\
E227 & Calcium hydrogensulphite & $\mathrm{Ca}_{3}\left(\mathrm{HSO}_{3}\right)_{2}$ \\
E228 & Potassium hydrogensulfite & $\mathrm{KHSO}_{3}$ \\
\hline
\end{tabular}

be used as antioxidants (FAO, 2006).

Sulphur dioxide is colorless, nonflammable, with a strong and suffocating odor, whereas sulfides occur as powder, crystals or granules of white color with a slight smell of sulphur dioxide. Sulphur dioxide and sulphites normally are being used in the production of wine, prior to the wort fermentation, to prevent the growth of harmful microorganisms that could therefore occur during fermentation. These compounds are further often used in a large number of foodstuffs, namely meat products with grains or vegetables, crustaceans and cephalopods, some species of salted and dried fish, fruits and dehydrated vegetables, crystallized, pulp, or in vinegar or brine, sweets, jams, jellies and jams, pie fillings, glucose syrups, dry biscuits, starches, potatoes, juices and drinks containing fruit juice, some types of beer, wine and other beverages, mustard, jelly and various substitutes for meat, fish or crustaceans, protein with vegetables (Voss, 2002).

Toxicity when legislated doses are applied is small, being sulphites eliminated in the urine (as sulfates). However, sulfur dioxide might destroy thiamine, being also stated that the use of these additives can lead to loss of vitamin B1. Allergic reactions in sensitive individuals (namely, asthma, headaches, stomach or skin irritation, eczema, nausea, diarrhea) have also been reported and, although not proved, their action in the development of cancer has been pointed (Voss, 2002; Inetianbor et al., 2015). Sulfites are also mutagens for some bacteria, but its mutagenic effect in humans is still under discussion (Voss, 2002; Oficial Journal of the European Union, 1999). By 2008, the additive 4-hexylresorcinol $\left(\mathrm{C}_{12} \mathrm{H}_{18} \mathrm{O}_{2}\right)(\mathrm{E} 586)$ has been authorized to be used as an alternative to sulfites, to prevent browning of crustaceans, fresh shellfish, frozen and deepfrozen. Moreover, some studies indicate that this additive has some estrogenic activity (Lidon and Silvestre, 2010).

\section{Nitrites and nitrates}

The potassium nitrite $\left(\mathrm{KNO}_{2}\right)$, sodium nitrite $\left(\mathrm{NaNO}_{2}\right)$, E249 and E250 respectively, as well as sodium nitrate $\left(\mathrm{NaNO}_{3}\right)$ and potassium nitrate $\left(\mathrm{KNO}_{3}\right), \mathrm{E} 251$ and E252 
respectively, are widely used as preservatives (Table 4) and color fixatives in the agro food industry related to meat products, such as hams, bologna, sausages, bacon etc. Nitrites are often also added to mixtures to be included during meat healing, to obtain typical color of cured meat (namely, ham and sausage). These inorganic substances are of synthetic origin, but also exist in nature as minerals.

The legislation of EU have set the levels of nitrates and nitrites in meat products, striving to achieve the desired technological aim and at the same time, the maintenance of public health. As potent inhibitors of Clostridium botulinum, nitrites and nitrates contribute effectively to prevent cases of botulism. While it is essential the use of nitrites and nitrates in foodstuffs, their use is not without risks to health.

Regarding side effects, the Scientific Committee for Food of the EU (Directive 2008/7/CE, 2008), in 22 September 1995 reported that in meat products nitrates turn into nitrites (e.g., by heating). Nitrites, in turn, react with acids (for example the existing hydrochloric acid in the stomach) and lead to the formation of nitrous acid $\left(\mathrm{HNO}_{2}\right)$, which in turn can react with certain amines (obtained by the hydrolysis of proteins) and form nitrosamines (Directive 2008/7/CE, 2008). Moreover, nitrosamines are genotoxic carcinogens and there is no threshold below which the formation of cancerous cells and tumors can be excluded (Oficial Journal of the European Union, 1999). There are also reports of other side effects, in particular antihypertensive effects favoring histaminic reactions and toxic effects especially for babies (due to methemoglobin formation from nitrite which might cause destruction of vitamins A, B1 and B2) (Lidon and Silvestre, 2007, 2008, 2010).

\section{Acetic acid and acetates}

The vinegar preservative action has been known for a long time and arises from the presence of acetic acid (Fig. 4).
This carboxylic acid has been used as food additive (E260) with preservative functions, acidity regulator and acidifiers. It inhibits the development of yeast, bacteria and fungi.

It can be used as free acetic acid or as sodium, potassium and calcium acetates (E261, E262 and E263) (Table 5). Some of these salts may have other functions.

Acetic acid is a colorless liquid or crystalline solid, being acetates white crystalline powders or granules. As preservatives these additives have a large spectrum of applications, namely in most food products, including mustard, vinaigrette sauce, fruit and vegetable preserves, canned fish, bread, mozzarella cheese and cream cheese, instant puddings and baby food. Acetic acid or acetates show no side effect.

\section{Propionic acid and propionates}

Propionic acid (Fig. 5; Table 6) is very tight in nature and produces the propionic fermentation of some types of cheeses.

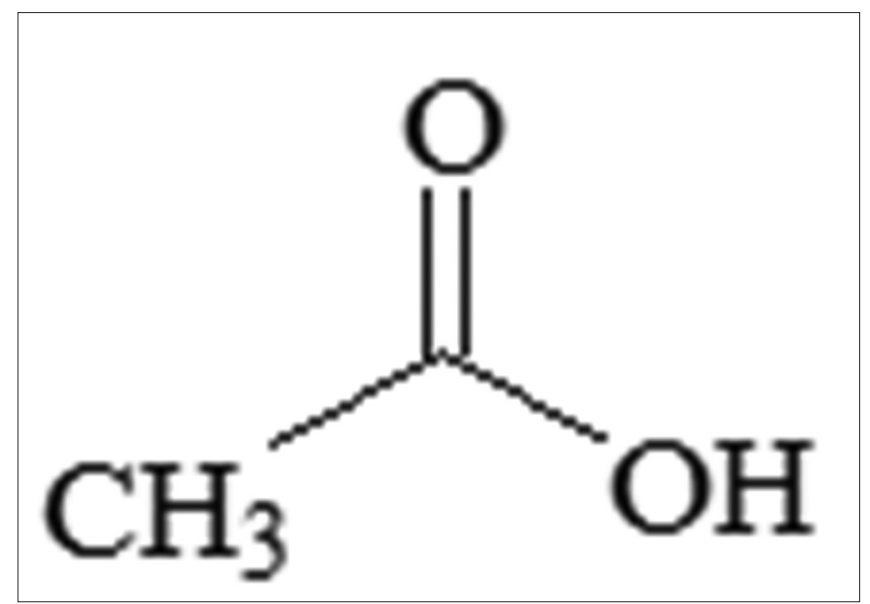

Fig 4. Acetic acid (E260) structure.

Table 4: Nitrite and nitrates used as food preservatives

\begin{tabular}{|c|c|c|c|c|c|}
\hline $\begin{array}{l}\text { Additive } \\
\text { code }\end{array}$ & Designation & $\begin{array}{l}\text { Chemical } \\
\text { formula }\end{array}$ & Foodstuff & $\begin{array}{l}\text { Amount added } \\
\left(\mathrm{mg} \mathrm{kg}^{-1}\right)\end{array}$ & $\begin{array}{l}\text { Residual quantity } \\
\left.\text { (mg kg }{ }^{-1}\right)\end{array}$ \\
\hline E249 & Potassium nitritea $^{a}$ & $\mathrm{KNO}_{2}$ & $\begin{array}{l}\text { Salt and sausage products, including blood and other } \\
\text { filled not heat-treated, cured and dried }\end{array}$ & $150^{b}$ & $50^{c}$ \\
\hline E250 & Sodium nitritea ${ }^{a}$ & $\mathrm{NaNO}_{2}$ & $\begin{array}{l}\text { Salt and sausage products, including blood and other } \\
\text { sausages } \\
\text { Products meat pickled. Foie gras. } \\
\text { Bacon }\end{array}$ & $150^{\mathrm{b}}$ & $\begin{array}{l}100^{\circ} \\
175^{\circ}\end{array}$ \\
\hline E251 & Sodium nitrate & $\mathrm{NaNO}_{3}$ & $\begin{array}{l}\text { Sausage and smoked products, including blood and } \\
\text { other sausages } \\
\text { Products of meat pickled }\end{array}$ & 300 & $250^{d}$ \\
\hline E252 & Potassium nitrate & $\mathrm{KNO}_{3}$ & $\begin{array}{l}\text { Hard cheese, semi-hard and semi-soft } \\
\text { Substitutes for cheese-based dairy products } \\
\text { Pickled herring and sprat }\end{array}$ & & $\begin{array}{c}50^{\mathrm{d}} \\
200^{\mathrm{e}}\end{array}$ \\
\hline
\end{tabular}

a) When they were labeled for food use, nitrite may only be sold in a mixture with salt or a salt substitute; b) Expressed as $\mathrm{NaNO}_{2}$; c) Residual amount at point of sale to the final consumer, expressed as $\mathrm{NaNO}_{2}$; d) Expressed as $\mathrm{NaNO}_{3}$; e) Residual amount expressed as $\mathrm{NaNO}_{2}$ including nitrite formed from nitrate 
Relatively to the antimicrobial action, propionic acid is more efficient in the control of fungi than in bacteria, and has virtually no effect in the presence of yeast. Accordingly, is being used commonly as a preservative (E280) in various types of bread pre-packed and pre-packed bakery products, being an efficient inhibitor of mold. It is also used to prevent abnormal development of Bacillus mesenteries, as well as in the treatment of cheeses surface (dipping the cheese in $8 \%$ solutions) and substitutes. Sodium, calcium and potassium propionates, which have strong smell acid, are also being used to achieve similar goals. Propionic acid and its salts did not show toxicity in the amounts permitted by the EU regulation (Voss, 2002).

\section{Antibiotics}

The use of antibiotics in food preservation is problematic since it can lead to the development of resistant microorganisms, with the consequent negative effects that this implies in its therapeutic application. Antibiotics nisin (E234) and pimaricin (natamycin - E235) have been used as food preservatives (Table 7; Fig. 6).

The antibiotic nisin has a certain importance as a food preservative (E234). Nisin is a natural active polypeptide across the Gram-positive microorganisms (lactic acid bacteria, streptococci, bacilli and clostridia anaerobic spores of other producers) (Suganthi et al., 2012). E234 is usually used in hard cheeses and processed cheeses, in particular to prevent butyric fermentation and white mold. The addition of nisin to canned vegetables allows the use of very mild sterilization conditions. It is also used in puddings semolina, tapioca, and the like.

The natamycin or pimaricin (E235) is an antibiotic action polypeptide, synthesized by microorganisms and active against yeasts and fungi. This antibiotic is used as a food preservative and has been applied for the surface treatment of cheese and also against the formation of fungi in dry sausage.

\section{Other preservatives}

Other preservatives (E230, E231, E232, E239, E242, E284, E285, E1105) are still being used in the EU (Table 8; Fig. 7).

E230 is an additive obtained by synthesis from coal tar. Incidentally, from Table 8 only E1105 is of natural origin. The diphenyl (E230), orthophenylphenol (E231) and the sodium salt of the latter (E232) are fungicides used for treatments of citrus fruit surface. In some soft drinks, and liquid tea, dimethyldicarbonate (E242) has been used to control the growth of fungi, yeasts and bacteria, whereas in provolone cheese E239 is being used. Diphenyl is used for impregnating the material where citrus are packed,
Table 5: Acetate and acetic acid used as preservatives

\begin{tabular}{|c|c|c|}
\hline $\begin{array}{l}\text { Additive } \\
\text { code }\end{array}$ & Designation & Chemical formula \\
\hline E260 & Acetic Acid & $\mathrm{CH}_{3} \mathrm{COOH}$ \\
\hline E261 & Potassium acetate & $\mathrm{CH}_{3} \mathrm{COOK}$ \\
\hline E262 & $\begin{array}{l}\text { Sodium acetates } \\
\text { (i) sodium acetate } \\
\text { (ii) sodium diacetate, } \\
\text { Sodium hydrogen diacetate }\end{array}$ & $\begin{array}{l}\mathrm{CH}_{3} \mathrm{COONa} \cdot \mathrm{nH}_{2} \mathrm{O}(\mathrm{n}=0,3) \\
{\left[\left(\mathrm{CH}_{3} \mathrm{COO}\right)_{2} \mathrm{H}\right] \mathrm{Na} \cdot \mathrm{nH}_{2} \mathrm{O}}\end{array}$ \\
\hline E263 & Calcium acetate & $\left(\mathrm{CH}_{3} \mathrm{COO}\right)_{2} \mathrm{Ca} \cdot \mathrm{H}_{2} \mathrm{O}$ \\
\hline
\end{tabular}

Table 6: Propionates and propionic acid used as preservatives

\begin{tabular}{lll}
\hline Additive code & Designation & Chemical formula \\
\hline E280 & Propionic acid & $\mathrm{CH}_{3} \mathrm{CH}_{2} \mathrm{COOH}$ \\
E281 & Sodium Propionate & $\mathrm{CH}_{3} \mathrm{CH}_{2} \mathrm{COONa}$ \\
E282 & Calcium Propionates & $\left(\mathrm{CH}_{3} \mathrm{CH}_{2} \mathrm{COO}\right)_{2} \mathrm{Ca}$ \\
E283 & Potassium Propionate & $\mathrm{CH}_{3} \mathrm{CH}_{2} \mathrm{COOK}$ \\
\hline
\end{tabular}

Table 7. Antibiotics used as preservatives

\begin{tabular}{lll}
\hline Additive code & Designation & Chemical formula \\
\hline E234 & Nisin & $\mathrm{C}_{143} \mathrm{H}_{230} \mathrm{~N}_{42} \mathrm{O}_{37} \mathrm{~S}_{7}$ \\
E235 & Pimaricin, natamycin & $\mathrm{C}_{33} \mathrm{H}_{47} \mathrm{NO}_{13}$ \\
\hline
\end{tabular}

Table 8. Other food preservatives

\begin{tabular}{|c|c|c|}
\hline $\begin{array}{l}\text { Additive } \\
\text { code }\end{array}$ & Designation & Chemical formula \\
\hline E230 & Biphenyl, diphenyl & $\mathrm{C}_{6} \mathrm{H}_{5} \mathrm{C}_{6} \mathrm{H}_{5}$ \\
\hline E231 & Orthophenylphenol & $\mathrm{C}_{6} \mathrm{H}_{5} \mathrm{C}_{6} \mathrm{H}_{4} \mathrm{OH}$ \\
\hline E232 & $\begin{array}{l}\text { Orthophenylphenol sodium salt, } \\
\text { sodium orthophenylphenol }\end{array}$ & $\mathrm{C}_{6} \mathrm{H}_{5} \mathrm{C}_{6} \mathrm{H}_{4} \mathrm{ONa} .{ }_{4} \mathrm{H}_{2} \mathrm{O}$ \\
\hline E239 & $\begin{array}{l}\text { Hexamethylenetetramine, } \\
\text { methenamine, hexamine }\end{array}$ & $\mathrm{C}_{6} \mathrm{H}_{12} \mathrm{~N}_{4}$ \\
\hline E242 & $\begin{array}{l}\text { Dimethyldicarbonate, diethyl } \\
\text { pyrocarbonate }\end{array}$ & $\mathrm{O}\left(\mathrm{CO}_{2} \mathrm{CH}_{3}\right)_{2}$ \\
\hline E284 & Boric acid & $\mathrm{H}_{3} \mathrm{BO}_{3}$ \\
\hline E285 & Sodium tetraborate, borax & $\mathrm{Na}_{2} \mathrm{~B}_{4} \mathrm{O}_{7}$ \\
\hline E1105 & Lysozyme & 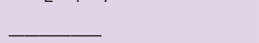 \\
\hline
\end{tabular}

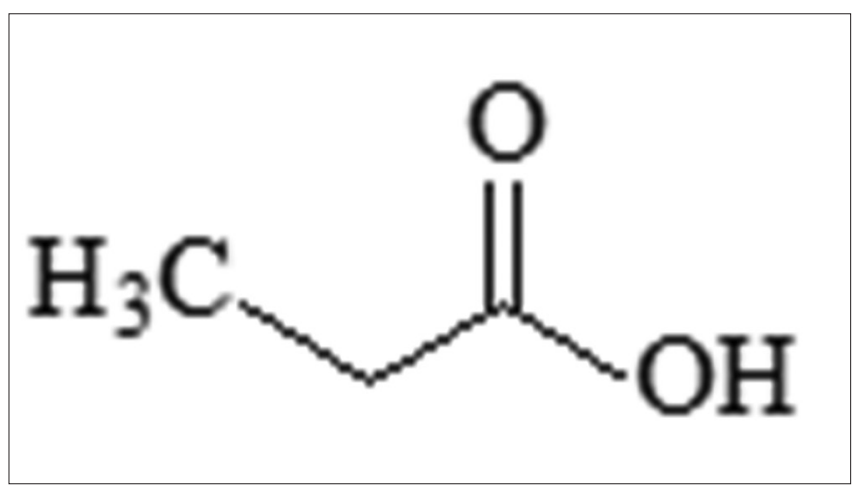

Fig 5. Propionic acid (E280) structure.

whereas orthophenylphenol (E231) is used submerging citrus fruits in basic solution.

Relatively to the side effects, it has been reported (Voss, 2002) that E230 and E231 to E232 may cause allergic 


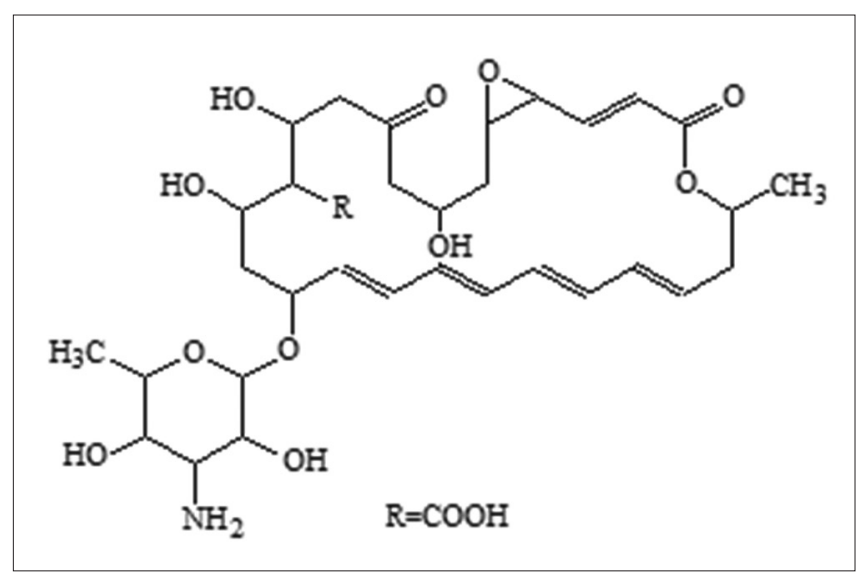

Fig 6. Natamycin or pimaricin (E235) structure.

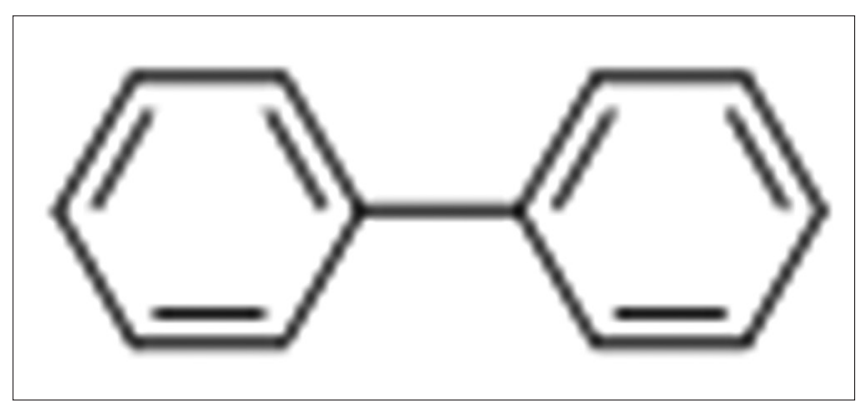

Fig 7. Diphenyl (E230) structure.

reactions in the skin, nausea, vomiting and irritation of the eyes and nose. In animal experiments, internal bleeding and mutagenic changes of the organs were also observed when these additives were used at high doses (Voss, 2002). Possible carcinogenicity to humans triggered by E231 and E232 has also been pointed (Voss, 2002). E239 has side effects because it is obtained from ammonia and formaldehyde, which indicate the release of formaldehyde. It appears to be an allergenic substance that can cause gastro-intestinal or urinary disturbances. The formation of potentially carcinogenic nitrosamines and their mutagenicity has been observed in some bacteria. Relatively to E242, the possible formation of a small amount of pesticide methylcarbonate, whose safety in relation to cancer has not been established has been indicated (Lidon and Silvestre, 2007). Boric acid, $\mathrm{H}_{3} \mathrm{BO}_{3}$ (E284) and sodium tetraborate, also known as borax, $\mathrm{Na}_{2} \mathrm{~B}_{4} \mathrm{O}_{7}$ (E285), are used in sturgeon eggs (i.e., caviar). Cases of poisoning by these products have been reported (Voss, 2002; See et al., 2010) and its repeated ingestion may cause diarrhea and internal organ damage (Voss, 2002). Lysozyme (E1105) is a natural preservative derived from egg white. This protein has been used in cheeses, because it hydrolyses the cell wall of many bacteria, particularly Gram-positive bacteria, thus preventing the late formation of gas due to the clostridia. It only has side effects in people with allergies to egg white.

\section{CONCLUSION}

There are a significant number of food preservatives (antimicrobial agents) that protect foodstuff against the action of microorganisms (fungi and/or bacteria) and thereby extend the shelf life. Jointly to other techniques, such as hermetically sealed packaging and cooling, food preservatives have an incontestable importance in food technology. The agro food companies use preservatives in pre-cooked food, meat products, sauces, cheese, canned fish, meat, vegetables and fruits, packaged bread, confectionery, cooked and frozen crustaceans, and many other food products in which case all additives and all uses are regulated by the EU. However, the use of some of these food additives is not absent side effects to health. Food preservatives, such as nitrites and sodium and potassium nitrates, the various benzoates, sulphites, diphenyl, orthophenylphenol and hexamethylenetetramine present meaningful side effects, and should be used in the smallest possible amount, maintaining the necessary technological features. Moreover, other food preservatives, such as sorbic acid and sorbates, acetic acid and acetates, propionic acid and propionates, when applied to foodstuffs do not appear to have side effects in the amounts indicated by the EU regulation.

\section{Authors contributions}

Both the authors of the paper contributed equally to the writing of the paper and were involved in the overall planing and supervision of the work.

\section{REFERENCES}

Abdulmumeen, H. A., A. N. Risikat and A. R. Sururah. 2012. Food: Its preservatives, additives and applications, Int. J. Chem. Biochem. Sci. 1: 36-47.

Directive 2000/63/CE of the European Parliament and of the Council of 5 October 2000.

Directive 2001/30/CE of the European Parliament and of the Council of 2 May; 2001.

Directive 2002/46/CE of the European Parliament and of the Council of 10 June; 2002.

Directive 2003/115/CE of the European Parliament and of the Council of 22 December; 2003.

Directive 2008/7/CE of the European Parliament and of the Council of 10 March; 2008.

Directive 95/2/EC of the European Parliament and of the Council of 20 February; 1995.

Directive 95/31/CE of the European Parliament and of the Council of 5 July; 1995.

Directive 95/45/CE of the European Parliament and of the Council of 26 July; 1995.

Directive 96/77/CE of the European Parliament and of the Council of 2 December; 1996.

Directive 96/83/CE of the European Parliament and of the Council of 19 December; 1995. 
Directive 96/83/CE of the European Parliament and of the Council of 19 December; 1996.

Directive 96/85/CE of the European Parliament and of the Council of 19 December; 1996.

Directive 98/66/CE of the European Parliament and of the Council of 5 July; 1998.

Directive 98/72/CE of the European Parliament and of the Council of 15 October; 1998.

Directive 99/41/CE of the European Parliament and of the Council of 8 July; 1999.

Directive 99/75/CE of the European Parliament and of the Council of 22 July; 1999.

FAO. 2006. Available from: http://www.fao.org/ag/agn/jecfa-additives/ search.html [Last accessed on 2015 Oct 15].

Inetianbor, J. E., J. M. Ykubu and S. C. Ezeonu. 2015. Effects of food additives and preservatives on man $-\mathrm{A}$ review. Asian J. Sci. Technol. 6(2): 1118-1135.

Lidon, F. C. and M. M. A. Silvestre. 2007. Industrias Alimentares Aditivos e tecnologias. Escolar Editora, Lisbon.
Lidon, F. C. and M. M. A. Silvestre. 2008. Conservação de Alimentos - Princípios e Metodologias, Escolar Editora, Lisbon.

Lidon, F. C. and Silvestre, M. M. A. S. 2010. Princípios de Alimentação e Nutrição Humana. Escolar. Editora, Lisbon.

Oficial Journal of the European Union. 1999. Commission decision of 26 October 1999 on the national provisions notified by the Kingdom of Denmark concerning the use of sulphites, nitrites and nitrates in foodstuffs. Vol. 329. Pp. 1-14.

See, A. S., A. B. Salleh, F. A. Bakar, N. A. Yusof, A. S. Abdulamir and L. Y. Heng. 2010. Risk and health effect of boric acid. Am. J. Appl. Sci. 7(5): 620-627.

Suganthi, V., E. Selvarajan, C. Subathradevi and V. Mohanasrinivasan. 2012. Lantibiotic nisin: Natural preservative from Lactococcus Lactis. Int. Res. J. Pharm. 3(1): 13-19.

Tuormaa, T. E. 1994. The additives effects of food additives on health: A review of the literature with special emphasis on childhood hyperactivity. J. Orthomol. Med. 9(4): 225-243.

Voss, C. 2002. Veneno no seu prato? Utilidades e riscos dos aditivos alimentares. $1^{\text {a }}$ ed. EDIDECO - Editores Para a defesa do consumidor Lda. Lisboa. 